\title{
PERAN ORANG TUA DALAM PROSES PEMBELAJARAN PENDIDIKAN AGAMA ISLAM DI MASA PANDEMI COVID-19
}

Ach. Syaikhu

Institue Agama Islam Al-Falah Assunniyah Kencong

Ach.Syaikhu1@gmail.com

\begin{abstract}
The Covid-19 pandemic has not ended until today. The spread of this virus give major impact, one of which is the necessity of a regional quarantine policy. In suppressing the number of the spread of covid-19, the Indonesian government has implemented a regional quarantine system (Lockdown) and PSBB (Large-Scale Social Restrictions) in line with the Decree of the Presidential Regulation of the Republic of Indonesia Number 99 of 2020 for the DKI Jakarta area and the Decree of the Minister of Health of Republic Indonesia Number HK.01.07/Menkes/248/2020 concerning the Determination of PSBB in Several Areas of West Java Province (Task Force for Handling COVID-19, 2020). This has an impact on various sectors of life, one of which is the education sector. The role of parents during the Pandemic has increased by supervising and accompanying children in the learning process. In this paper, the author wants to explain the role of parents in assisting the learning process of Islamic Religious Education in children during the Covid-19 pandemic.
\end{abstract}

Keywords: Role of Parents, Islamic Religious Education, Covid-19 Pandemic

\section{Pendahuluan}

WHO (World Health Organization atau Badan Kesehatan Dunia) secara resmi mendeklarasikan virus corona (COVID-19) sebagai pandemi pada tanggal 9 Maret 2020. Berdasarkan data WHO yang telah terkonfirmasi covid-19 sebanyak 42,9 juta dengan jumlah kematian 1,12 juta (WHO, 2020). ${ }^{1}$ Penyebaran virus ini memberikan dampak besar salah satunya diharuskannya kebijakan karantina wilayah. Dalam menekan angka penyebaran covid-19, pemerintah Indonesia memberlakukan sistem karantina wilayah (Lockdown) dan PSBB (Pembatasan Sosial Berskala Besar) pada

\footnotetext{
${ }^{1}$ World Health Organization, "WHO Coronavirus Disease (COVID-19) Dashboard," World Health Organization, , accessed Oct 28, 2020, https://covid19.who.int/.
} 
keputusan Peraturan Presiden Republik Indonesia Nomor 99 Tahun 2020 untuk wilayah DKI Jakarta dan Keputusan Menteri Kesehatan Republik Indonesia Nomor HK.01.07/Menkes/248/2020 tentang Penetapan PSBB di Beberapa Wilayah Provinsi Jabar (Satgas Penanganan COVID-19, 2020). ${ }^{2}$ Tentu saja, hal tersebut memberikan dampak pada berbagai sector kehidupan salah satunya sektor pendidikan.

Indonesia telah memberlakukan kebijakan Pembelajaran Jarak Jauh sesuai dengan Surat Edaran Nomor 4 Tahun 2020 yang berisi tentang Pelaksanaan Kebijakan Pendidikan dalam Masa Darurat Penyebaran Coronavirus Disease (Covid-19) yang dikeluarkan pada tanggal 24 Maret 2020 oleh Kemendikbud. pelaksanaan Pembelajaran Jarak Jauh (PJJ) mengharuskan murid dan mahasiswa melaksanakan pembelajaran menggunakan daring dan virtual seperti penggunaan platform zoom, google meet, website kampus dan media daring lainnya. Namun, dalam proses pembelajaran daring atau virtual masih banyak siswa, tenaga pengajar dan orang tua merasa keberatan oleh situasi tersebut. Metode daring dinilai belum disiapkan sepenuhnya untuk dijadikan sistem belajar diterapkan sekolah dalam pelaksanaan pembelajaran jarak jauh saat ini dinilai tidak efektif karena sekolah daring belum mampu menggantikan sekolah tatap muka. Hal ini menyebabkan masih banyak kendala dan dampak yang terjadi khususnya dalam pembelajaran pendidikan agama Islam pada pembelajaran jarak jauh.

Pendidikan agama Islam merupakan system pendidikan yang mengarahkan dan membimbing peserta didik untuk dapat sesuai dengan ideologi Islam. Ideologi islam tersebut berdasarkan tuntunan umat islam yaitu Al-Quran dan Hadits. Terlebih untuk anak yang masih dalam bimbingan orang tua seperti siswa pada sekolah dasar dan menengah. Peran orang tua sangatlah besar sebagai sarana dan contoh anak dalam belajar mengingat di masa pandemic covid-19 kebutuhan pendidikan yang layak bagi anak tidak dapat terpenuhi dengan baik dari sekolah maupun tenaga pengajar. Disinilah peran orang tua mendampingi dan membimbing anak dalam hal pendidikan islam karena terutama orang tua bukan hanya menjadi lingkungan pertama tapi juga lingkungan utama dalam pandangan islam dalam hal pendidikan

\footnotetext{
${ }^{2}$ Satgas Penanganan COVID-19, "Regulasi,” Satgas Penanganan COVID-19, accessed Nov 10,2020, https://covid19.go.id/p/regulasi.
} 


\section{Ach. Syaikhu}

\section{Pembahasan}

\section{Pendidikan Agama Islam}

Menurut Ahmad Tafsir, Pendidikan Agama Islam adalah bimbingan yang diberikan oleh seseorang kepada seseorang agar ia berkembang secara maksimal sesuai dengan ajaran Islam. Bila disingkat, pendidikan agama Islam adalah bimbingan terhadap seseorang agar menjadi muslim semaksimal mungkin. ${ }^{3}$ Sedangkan menurut Zuhairini, Pendidikan Agama Islam adalah usaha sadar untuk membimbing ke arah pembentukan kepribadian peserta didik secara sistematis dan pragmatis, supaya hidup sesuai dengan ajaran Islam, sehingga terjadinya kebahagiaan dunia akhirat. ${ }^{4}$ Dari pendapat-pendapat tersebut, dapat disimpulkan bahwa Pendidikan Agama Islam merupakan suatu proses pembentukan perubahan sikap dan tingkah laku sesuai dengan petunjuk ajaran agama Islam.

Pendidikan agama Islam tidak akan terlepas dari sebuah tujuan yang ingin dicapai. Dalam hal ini, ada beberapa tujuan pendidikan agama Islam antara lain:

i. Tujuan Umum (Institusional)

Tujuan umum meliputi seluruh aspek kemanusian antara lain sikap, tingkah laku, penampilan, kebiasaan, dan pandangan. Tujuan umum ini diejawantahkan sebagai proses membentuk manusia sempurna (insan kamil) yang mampu melaksanakan tugasnya baik sebagai seorang Abdullah maupun Khalifatullah. Tujuan umum pendidikan harus dikaitkan pula dengan tujuan pendidikan nasional Negara tempat pendidikan Islam itu digunakan dan harus dikaitkan pula dengan tujuan institusional.

ii. Tujuan Sementara (Instruksional)

Tujuan sementara adalah tujuan yang akan dicapai setelah seseorang didik diberi sejumlah pengalaman tertentu yang direncanakan dalam suatu kurikulum pendidikan formal.

\footnotetext{
${ }^{3}$ Ahmad Tafsir, Ilmu Pendidikan Dalam Perspektif Islam, (Bandung: PT Remaja Rosdakarya, 1992), hal. 32

${ }^{4}$ Zuhairini, Metodologi Pembelajaran Pendidikan Agama Islam, (Malang: UIN Press, 2004), hlm. 11
} 
iii. Tujuan Operasional

Tujuan Operasional adalah tujuan praktis yang akan dicapai dengan sejumlah kegiatan tertentu. Dalam tujuan operasional ini lebih banyak dituntut dari seseorang didik suatu kemampuan dan keterampilan tertentu. Sifat operasionalnya lebih ditonjolkan dari sifat penghayatan dan kepribadian. Untuk tingkat yang paling rendah, sifat yang berisi kemampuan dan keterampilanlah yang ditonjolkan.

iv. Tujuan Akhir

Pendidikan Islam merupakan proses yang berlangsung selama hidup, maka tujuan akhirnya tedapat pada waktu hidup di dunia ini telah berakhir pula. Tujuan akhir Pendidikan Agama Islam akan dapat lebih dipahami dalam firman Allah SWT:

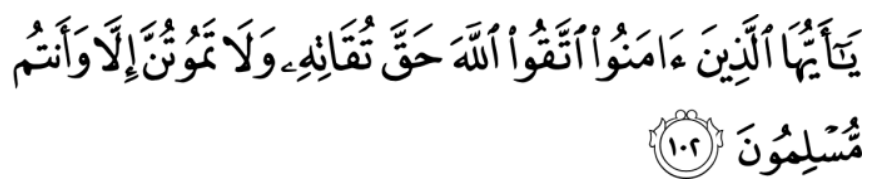

Artinya: "Hai orang-orang yang beriman, bertakwalah kepada Allah sebenarbenar takwa kepadaNya, dan janganlah sekali-kali kamu mati melainkan dalam keadaan beragama Islam.” (QS. Al-Imran: 102)

Dalam proses pendidikan agama Islam pun taka pat terlepas dari muatan materi yang menjadi salah satu indicator kesukesan pencapaian tujuan dari pendidikan agama Islam tersebut. Adapun materi pokok pendidikan aga Islam dapat diklasifikasina dalam 5 aspek antara lain:

i. Aspek Al-Quran dan Hadist.

Dalam aspek ini menjelaskan beberapa ayat dalam Al-Qur'an dan sekaligus juga menjelaskan beberapa hukum bacaannya yang terkait dengan ilmu tajwid dan juga menjelaskan beberapa hadist Nabi Muhammad Saw.

ii. Aspek Keimanan dan Aqidah Islam 
Dalam aspek ini menjelaskan berbagai konsep keimanan yang meliputi enam rukun iman dalam Islam.

iii. Aspek Akhlak

Dalam aspek ini menjelaskan berbagai sifat- sifat terpuji (akhlak karimah) yang harus diikuti dan sifat- sifat tercela yang harus dijahui.

iv. Aspek Hukum Islam

Dalam aspek ini menjelaskan berbagai konsep keagamaan yang terkait dengan masalah ibadah dan mu'amalah.

v. Aspek Tarikh Islam

Dalam aspek ini menjelaskan sejarah perkembangan atau peradaban Islam yang bisa diambil manfaatnya untuk diterapkan di masa sekarang. ${ }^{5}$

\section{Peran Orang Tua selama dalam Proses Pembelajaran Pendidikan Agama Islam Pandemi Covid 19}

Peran orang tua sangatlah besar pada proses belajar dan pembelajaran bagi anak, khususnya di masa pandemic ini. Bertambahnya peran untuk mengawasi dan mendampingi proses belajar anak saat belajar di rumah, orang tua perlu memiliki kemampuan ekstra dalam mengatur system belajar, emosi dan motivasi anak. Orang tua perlu meluangkan waktu ekstra untuk anak dalam mendampingi proses pembelajaran jarak jauh dengan daring. Tidak jarang orang tua harus ikut belajar bersama dan hal tersebut berpengaruh pada aktivitas rutin sehari-hari. Bagi anak pada sekolah dasar, pendampingan orang tua sangat diperlukan. Mulai dari persiapan yaitu menyiapkan alat dan sistem pembelajaran jarak jauh dengan daring juga membimbing anak agar dapat menggunakan teknologi untuk meningkatkan kualitas pembelajaran.

Dalam proses pembelajaran jarak jauh, orang tua sering menghadapi masalah dalam memahami metodologi pengajaran yang baru berbasis teknologi. Dengan demikian, mereka tidak dapat membimbing lingkungan mereka untuk mengambil kelas secara online. Tak hanya itu, permasalahan yang dihadapi

\footnotetext{
${ }^{5}$ Depdiknas Jendral Direktorat Pendidika Dasar, Lanjutan Pertama Dan Menengah, Pedoman Khusus Pengembangan Silabus Berbasis Kompetensi Sekolah Menengah Pertama,(Jakarta : 2004),hlm.18
} 
juga terkait fasilitas pendidikan berupa konektivitas internet. Hal tersebut juga menjadi tantangan besar di hadapan semua guru, siswa, dan orang tua. Banyak gangguan yang harus dihadapi karena konektivitas yang buruk (Preeti Tarkar 2020). ${ }^{6}$. Oleh karena itu, kendala lain disaat orang tua juga memiliki keterbatasan dalam penguasaan teknologi. Ditambah lagi adanya penambahan biaya pembelian kuota internet dengan proses pembelajaran jarak jauh yang juga memerlukan koneksi jaringan yang baik. Penambahan kuota internet juga menambah beban pengeluaran. Selama beberapa bulan sejak pandemi diperlukan kuota yang lebih banyak sehingga otomatis meningkatnya biaya pembelian kuota internet. Kemudian, hal ini dibarengi oleh kendala keterbatasan pengetahuan orang tua.

Orang tua harus mampu bersinergi dengan guru selama proses pembelajaran di masa pandemic covid-19 ini guna kelancaran proses belajarmengajar. Namun, ternyata orang tua sangat berperan penting selama pandemi. Khususnya pada pembelajaran Pendidikan Agama Islam (PAI), proses belajar mengajar bukan hanya teori tapi juga praktik. Hal ini menjadi kendala baik orang tua maupun guru. Kendala yang ada bagi orang tua, ketika orang tua memiliki keterbatasan pengetahuan pada pembelajaran agama Islam. Dimana orang tua mendampingi dari awal hingga akhir mulai dari pengajaran, pemahaman dan praktik. Oleh karena itu, orang tua baik praktek maupun teori dituntut untuk belajar dan harus paham betul materi yang akan diajarkan kepada anak. Bahkan, orang tua kadang ikut belajar dan mengajari anak seperti dalam hal mengajari dari cara menghafal hingga membetulkan bacaan-bacaan yang salah lalu di praktekan. Dalam proses tersebut guru kurang dapat bersinergi secara maksimal karena proses pembelajaran jarak jauh. Padahal, orang tua sebagai keluarga merupakan lingkungan pertama bagi pertumbuhan fisik juga perkembangan psikis anak dan pembelajaran agama. Dalam pandangan islam keluarga bukan hanya lingkungan pertama tetapi lingkungan utama. Hal ini menunjukkan betapa pentingnya orang tua dan guru dalam mengembangkan

\footnotetext{
${ }^{6}$ Preeti Tarkar, "Impact of COVID-19 Pandemic on Education System," International Journal of Advanced Science and Technology 29, no. 9 Special Issue (2020): 3812-14.
} 


\section{Ach. Syaikhu}

potensi anak-anak dengan mengajari dan menanamkan nilai-nilai keagamaan serta praktik ibadah sebagai awal dan pegangan anak dalam kehidupan mereka.

Kendala lainnya muncul, banyak anak mengeluh jenuh dengan sistem pembelajaran jarak jauh yang dinilai membosankan dan hanya menatap layar. Dengan pemberian materi dan tugas-tugas dikerjakan di rumah terus menerus. Dengan metode pembelajaran jarak jauh membuat anak perlu waktu beradaptasi akan perubahan sistem pembelajaran baru. Meskipun menggunakan sistem pembelajaran daring yang memudahkan dan menimbulkan kemandirian belajar tetapi sulit untuk mengontrol perkembangan pembelajaran pada anak sebagai murid. Maka timbul kendala selanjutnya, perkembangan pembelajaran anak dikarenakan anak memiliki daya serap dan gaya belajar yang berbeda. Oleh sebab itu, orang tua dituntut untuk mampu berinovasi dalam menciptakan lingkungan belajar di rumah yang menyenangkan.

\section{Penutup}

perkembangan setiap anak tidak dapat dipukul rata dan haruslah dipantau dengan baik. Pendampingan oleh orang tua sangat diperlukan terlebih anak pada sekolah dasar yang belum paham betul dengan teknologi. Pendampingan oleh orang tua dari awal hingga akhir pada proses pembelajaran jarak jauh dengan daring selama pandemic Covid-19, terutama menyangkut pada pembelajaran Agama Islam hingga anak sebagai murid paham yang diajarkan. Orang tua selama pandemi menjadi berperan penting dalam mendampingi anak. Sehingga hasil dalam proses pembelajaran dapat dipahami dan diserap dengan baik 


\section{DAFTAR PUSTAKA}

Ahmad Tafsir, Ilmu Pendidikan Dalam Perspektif Islam, (Bandung: PT Remaja Rosdakarya, 1992), hal. 32

Depdiknas Jendral Direktorat Pendidika Dasar, Lanjutan Pertama Dan Menengah, Pedoman Khusus Pengembangan Silabus Berbasis Kompetensi Sekolah Menengah Pertama,(Jakarta : 2004),hlm.18

Preeti Tarkar, "Impact of COVID-19 Pandemic on Education System," International Journal of Advanced Science and Technology 29, no. 9 Special Issue (2020): 3812-14.

Satgas Penanganan COVID-19, "Regulasi," Satgas Penanganan COVID-19, accessed Nov 10,2020, https://covid19.go.id/p/regulasi.

World Health Organization, "WHO Coronavirus Disease (COVID-19) Dashboard," World Health Organization, , accessed Oct 28, 2020, https://covid19.who.int/.

Zuhairini, Metodologi Pembelajaran Pendidikan Agama Islam, (Malang: UIN Press, 2004), hlm. 11 